\title{
Bank Lending Channel in Transmission of Monetary Policy in Japan, 2000-2012: The Sign Restrictions VAR Approach
}

\author{
Masao Kumamoto ${ }^{1}$, Juanjuan Zhuo ${ }^{2}$ \\ ${ }^{1}$ Department of Economics, Tokyo Keizai University, Tokyo, Japan \\ ${ }^{2}$ Graduate School of Economics, ,Tokyo Keizai University, Tokyo, Japan \\ Correspondence: Masao Kumamoto, Department of Economics, Tokyo Keizai University, 1-7-34, Minami-cho, \\ Kokubunji-shi, Tokyo, 185-8502, Japan.
}

Received: December 16, 2016

Accepted: January 6, $2017 \quad$ Available online: xx , 2017

doi:10.11114/aef.v4i2.2137

URL: http://dx.doi.org/10.11114/aef.v4i2.2137

\begin{abstract}
This paper investigates empirically whether the bank lending channel of monetary policy existed in Japan from 2000 to 2012. We employ the sign restrictions VAR approach to deal with the identification problem. In particular, we focus on the differential effects of a quantitative easing monetary policy regardless of bank (City banks vs. Regional banks) and firm (all enterprises vs. small and medium-sized enterprises-SMEs) size. Our impulse response function analyses show that following a quantitative easing monetary policy shock, the lending of Regional banks increases more than that of City banks, and the bank lending rate of Regional banks declines in a larger magnitude. Moreover, the responses of output to reserve supply are larger in Regional banks than that in City banks. Our variance decomposition analyses show that a larger proportion of the forecast error variance in the bank lending of Regional banks relative to City banks, and a larger proportion of the forecast error variance in the bank lending to SMEs relative to all firms can be explained by monetary policy shock. Similarly, the loans of Regional banks have a larger impact on output than the loans of City banks, and the loans to SMEs have a larger impact on output than the loans to all firms. Moreover, output is more affected by the reserve supply to Regional banks than to City banks. These results together indicate that a quantitative easing policy has a greater impact on the real economy through the lending of Regional banks.
\end{abstract}

Keywords: monetary policy, bank lending channel, Sign restrictions VAR, Japan

\section{Introduction}

The role of banks in the transmission of monetary policy has been a subject of theoretical and empirical studies over the past three decades. According to Bernanke and Blinder (1988), the role of banks in the transmission of monetary policy stems from not only their liability side, but also their asset side. For example, following a contractionary monetary policy, the banks' reserves decrease, and because of reserve requirements, their deposits also decrease. If banks cannot offset their decline in funds required for lending by switching from deposits to other forms of finance such as CDs, CPs and equities, they would have to reduce their loan supply. Furthermore, if some firms are bank-dependent and therefore cannot offset the decline in bank loans by switching their form of external finance by issuing corporate bonds or equities, their investment would fall and, consequently, the aggregate demand would fall.

Bernanke and Blinder (1988) and Kashyap and Stein (1994) pointed out three conditions for the existence of a bank lending channel; (i) deposits and other sources of finance are not perfect substitutes for banks, and hence banks cannot insulate their loan supply from a decline in bank reserves induced by monetary policy, (ii) bank loans and other sources of finance are not perfect substitutes for firms, and hence firms cannot unable to insulate their investments from a decline in bank loan supply, and (iii) the aggregate demand depends on both bank lending rate. Under these three assumptions, Bernanke and Blinder (1988) introduce bank loans into the conventional IS-LM framework so as to distinguish between money, bonds and bank loans. They show that the modified IS curve, derived by combining the commodity market and the credit market clearing conditions and thus called the "CC curve", depends on the volume of reserves. Thus, a change in reserves following monetary policy affects the LM curve as well as the CC curve. As a result, the effect on output is magnified compared to the case where only the interest rate channel exists. In particular, the existence of a bank lending channel is important under a "liquidity trap," where the semi-elasticity of money demand with respect to interest rate becomes so high that a quantitative easing monetary policy is ineffective in 
lowering the interest rates and stimulating the economy. However, if the bank lending channel exists, the CC curve can shift to the right and the output could therefore increase following a quantitative easing monetary policy.

The objective of this paper is to empirically investigate whether the bank lending channel has existed in Japan since the beginning of the quantitative easing monetary policy in the early 2000s (Note 1). This seems to be important when we consider that Japan could have been in a liquidity trap as argued by Krugman (1998a, 1998b).

In empirical analyses of the bank lending channel, estimations using aggregated macro-data are known to suffer from an identification problem: the inability to distinguish the change in bank loans after a monetary policy is attributed to the change in loan supply (bank lending channel) or to the change in demand for bank loans stemming from a change in investments (interest rate channel). Thus, previous studies have proposed several approaches to overcome the identification problem, including the "mix" variable, structural VAR (SVAR) model, and vector error correction model (VECM) approaches. Moreover, recent studies have resorted to the use of disaggregated data, micro-data or survey data (Note 2). The sign restrictions VAR method proposed by Uhlig (2005) is another new approach to deal with the identification problem. This paper employs the sign restrictions VAR approach to investigate the existence of the bank lending channel in Japan.

This analysis focuses especially on the differential effects of quantitative easing monetary policy regardless of bank and enterprise size. As for bank size, Kashyap and Stein $(1994,2000)$ show a substantial fall in small-bank lending compared to large-bank lending following a tight monetary policy, and that the bank lending channel matters more for the lending of small banks that have the least liquid balance sheets. As for firm size, Gertler and Gilchrist $(1993,1994)$ find substantial sales and short-term debt contracts (bank loans and CPs) for small firms relative to large firms after a contractionary monetary policy. Thus, the bank lending channel has larger effects on small firms that depending on banks and incurring higher agency costs.

The remainder of this paper is organized as follows. Section 2 overviews the related literature that empirically investigates the bank lending channel in the monetary policy transmission mechanism by employing the sign restrictions VAR approach. Section 3 shows the estimation methodology and results. Section 4 concludes the study.

\section{Literature Reviews}

Studies on the bank lending channel employing the sign restrictions VAR model identify at least two shocks; the loan supply shock and monetary policy shock. Busch, Scharnagl, and Scheithauer (2010) mention that it is not advisable to identify as many shocks as there are variables in the system because of higher computational costs. On the other hand, Kabashi and Suleva (2012) show that identifying only a few shocks can result in a large amount of unexplained movements. Therefore, several studies identify more than two shocks based on their main point of interest, such as the aggregate supply shock, aggregate demand shock and loan demand shock.

Hereafter, we use the expression "positive shock" or "expansionary shock" to represent a shock that increases output, and "negative shock" or "contractionary shock" to represent a shock that decreases output.

As discussed in Musso (2009), an aggregate supply shock is typically defined as a shock whose initial impact is on prices, and the other shocks as those whose initial impact is on production. Thus, the latter include the shock to the cost of production including oil prices, shock to the price setting behavior of firms and shock to technology. As further discussed in Musso (2009), the aggregate demand shock is defined as a residual category of shock affecting the components of aggregate demand, but it is distinguished from the money demand shock, monetary policy shock, loan supply shock and loan demand shock, which are usually considered components of the aggregate demand shock. Thus, it includes the consumption or preference shock, investment demand shock and fiscal policy shock (Note 3). A monetary policy shock refers to an unexpected change in monetary policy stance variables such as the policy rate or monetary base. A loan demand shock arises from changes in the access to alternative forms of finance or shifts in borrowers' preferred loan volume, that are not due to changes in macroeconomic variables. Loan supply shock is defined as changes in credit standards that are not caused by changes in macroeconomic variables. Therefore, it can be associated with various shocks, such as the unexpected changes in bank capital available for loans, for example, due to changes in regulatory capital constraints or the introduction of deposit insurance schemes; changes in the risk assessment of potential borrowers by banks, for example, due to innovations in bank monitoring technology or due to an unexpected change in credit default risk; changes in bank financial position; and changes in the degree of competition in the banking sector.

Some general agreements in the previous literature show how to identify each shock. Table 1 summarizes the typical sign restrictions. First, an aggregate supply shock is usually identified by assuming that it moves output and prices in opposite directions, while an aggregate demand shock moves them in the same direction. The response of the policy rate to these shocks is specified differently in the literature. Some studies assume that the policy rate rises in response to a negative aggregate supply shock (contemporaneous rise in prices but fall in output) and positive demand shock 
(contemporaneous rises in output and prices). Second, a contractionary monetary policy shock is identified by a rise in policy rate that causes a contemporaneous fall in output and prices. This restriction on prices distinguishes a monetary policy shock from an aggregate supply shock. Third, there is general consensus that a loan supply shock moves the loan volume and lending rate in opposite directions, whereas a loan demand shock moves them in the same direction. In addition, most studies assume an increase in output following a positive loan supply shock, because households would borrow more and use the funds to expand their consumption and firms would borrow more and use these funds to expand their investments. On the other hand, price and monetary policy reactions to these shocks are ambiguous. While increased consumption and investment expenditure imply inflationary pressures, a lower lending rate implies lower marginal cost of firms that would decrease the prices of their products. It is not clear as to which effect might prevail.

Table 1. Typical sign restrictions

\begin{tabular}{c|c|c|c|cc}
\hline & aggregate supply & aggregate demand & monetary policy & loan demand & loan supply \\
\hline$y$ & - & + & - & & + \\
$p$ & + & + & - & ambiguous & ambiguous \\
$i$ & $(+)$ & $(+)$ & + & ambiguous & ambiguous \\
$\rho$ & ambiguous & & & + & + \\
$l$ & ambiguous & & & + & - \\
\hline
\end{tabular}

Hereafter, we review the related studies that investigate the bank lending channel by using the sign restrictions VAR approach. Table 2 summarizes those studies.

Halvorsen and Jacobsen (2009) analyze the importance of a loan supply shock on the real activity in Norway and the United Kingdom. They use six endogenous variables: inflation, GDP gap (de-trended real GDP), the "mix" variable, the real effective exchange rate, the real house price, and the domestic short-term interest rate. They also use the (trade-weighted) foreign short-term interest rate as an exogenous variable. They identify two shocks, the loan supply shock and monetary policy shock. They use the "mix" variable, defined as the ratio of bank loans to households and non-financial corporations (hereafter NFCs) in the numerator to the sum of bank and non-bank credit to the same borrowers in the denominator, to capture the loan supply shock. As suggested by Kashyap, Stein, and Wilcox (1993), the mix variable contains information on loan demand. Following a contractionary monetary policy, for example, decreases in bank loans due to a decline in loan supply, firms will increase their non-bank credit. On the other hand, if a decline in loan demand is the main reason for the decrease in bank loans, the non-bank credit would also decrease. Thus, a negative loan supply shock decreases the mix variable. A zero restriction on a contemporaneous inflation response relies on short term price stickiness. A reduction in loan supply has a negative contemporaneous effect on the output gap. The domestic short term interest rate is assumed to respond negatively for two reasons. First, a negative loan supply shock is expected to decrease the banks' liability side, where an important funding source is the money market. Consequently, a negative loan supply shock might exert a downward pressure on the short-term interest rate. Second, the central bank might respond to a negative loan supply shock by decreasing the short-term interest rate, which in turn might lead to a depreciation of the exchange rate. They also assume that a reduction in loan supply has a negative impact on housing prices. As regards the contractionary monetary policy shock, they assume that the output gap and the mix variable will decrease, the exchange rate will appreciate and house prices will fall contemporaneously.

Musso (2009) identifies six shocks, the aggregate supply shock, loan demand shock, loan supply shock, money demand shock, monetary policy shock and "other aggregate demand" shock, and investigates the impact of these shocks on the macroeconomic variables in the United-States and the euro area countries. He uses eight variables: the real GDP, prices, short term interest rate, spread (difference between the lending rate and rate of return of broad money), broad money, loans to NFCs, ratio of broad money to loans, and loans to general government. He assumes that all the positive money demand, loan supply and loan demand shocks increase both output and prices, and thus lead to a rise in short term interest rates. These assumptions enable us to distinguish these shocks from monetary policy shock, which is characterized by a decrease in short term interest rates associated with increase in output and prices. Moreover, he assumes that the loans to NFCs will increase and the ratio of money to loans will decrease in reaction to the two positive credit shocks (demand and supply), while broad money and the ratio of money to loans will increase in response to the two positive money shocks (demand and supply).

Busch et al. (2010) study the role of the loan supply shock and monetary policy shock in the dynamics of loans to NFCs in Germany. They use six variables: loans, real GDP, prices (CPI), lending rate, short-term (overnight) interest rate and the spread between the corporate and government bond yields. They identify two shocks, loan supply shock and monetary policy shock. For a negative loan supply shock, they assume that lending rate and loan volume move in opposite directions over the first three quarters, because loans are highly persistent. The real GDP falls immediately and remains negative over the first three quarters. On the other hand, the decline in prices and short-term interest rate starts after the second and third quarter, respectively. These restrictions ensure that a negative loan supply shock is different from a contractionary monetary policy shock, after which the short-term interest rate is assumed to be positive for the 
first three quarters. For an expansionary monetary policy shock, the lending rate also falls with a lag of one quarter and the loan volume is expected to increase correspondingly. The prices increase with a lag of tow quarter, after which the loan volume increases.

De Nicoló and Lucchetta (2010) use a dynamic factor model to present a framework that jointly forecasts the indicators of systemic real risk and systemic financial risk in the G-7 countries. Systemic real risk is defined as a shock triggering a significant decline in real activity, whereas systemic financial risk is defined as a shock triggering a loss of economic value or confidence in a substantial portion of the financial system. They identify four shocks, the aggregate supply, the aggregate demand, loan supply and loan demand shocks in the usual manner. They do not impose restrictions on the loan volume and lending rate responses to the aggregate supply and aggregate demand shocks, because their signs are ambiguous. For example, a negative aggregate demand shock can induce the NFCs to decrease their loan demand, which would then reduce the lending rate. At the same time, the adverse wealth effects of a negative aggregate demand shock might induce banks to reduce their loan supply, because they may become increasingly capital constrained or risk averse, which would then increase the lending rate.

Deryugina and Ponomarenko (2011) investigate which shock contributed to the decrease in bank lending in Russia after the Lehman Brothers collapse, the loan supply shock or monetary policy shock. They consider deposits as a monetary stance variable, because money markets are relatively insignificant and short-term interest rates are highly volatile in Russia. Moreover, money stock in Russia is directly affected by the central bank's foreign exchange interventions and fiscal policy. Therefore, they conclude that deposits may be superior to other measures (short-term interest rate or money stock). They use five variables, GDP, prices (GDP deflator), short-term interest rate, loans, and deposits, and generally follow Busch et al. (2010) with regard to sign restrictions. They differ from Busch et al. (2010) in that they identify an expansionary monetary policy shock by an increase in deposit and do not assume a contractionary monetary policy in response to a positive loan supply shock.

Eickmeier and $\mathrm{Ng}$ (2011) investigate how the loan supply shocks in the United-States., the euro area and Japan transmit to other economies. They use the global VAR (GVAR) approach to model the financial variables jointly with macroeconomic variables in 33 countries. They assume that after a negative loan supply shock, the loan volume declines, and the GDP declines as well, but not as much as the loans. Therefore, the ratio of loans relative to the GDP will decrease. This restriction distinguishes the loan supply shock from the aggregate demand and supply shocks, following which the GDP reacts more strongly than loans. The corporate bond rate, the spread between the corporate bond rate and long-term government bond yield, and the spread between the corporate bond rate and short-term interest rate are all assumed to increase. The restriction on the response of the corporate bond yield / long-term government yield spread implies an increase in credit risk premium under a negative loan supply shock. The restriction on the corporate bond yield/short-term interest rate spread distinguishes the loan supply shock from a contractionary monetary policy shock, which would lower the spread. The responses of inflation and short-term interest rate are unrestricted. Sign restrictions are imposed on loans and GDP over the first three quarters following the shock, while those on the loan-to-GDP ratio and on the corporate bond rate and spreads are imposed only at the moment of shock to allow for short-term and government bond rates to adjust quickly to the shock.

Helbling, Huidrom, Kose, and Otrok (2011) identify the credit market shock and productivity shock to examine the role of these shocks in the global and U.S. business cycles. First, they extract the first principal component of each macroeconomic variable: loans, GDP, labor productivity, inflation, and short-term interest rate in the G-7 countries. Next, they estimate the VAR model, which includes the U.S. credit spread and default rates in addition to the estimated global factors. Moreover, they examine the transmission of the credit market shock originating in the U.S. to the global economy by using a factor-augmented VAR (FAVAR) model. They distinguish a negative loan supply shock from a negative aggregate supply shock by assuming that the former leads simultaneously to a decrease in loans and an increase in credit spreads. In addition, they assume that productivity does not fall and that the default rates do not rise. Restrictions on productivity and default rates ensure that they identify a credit market shock rather than an endogenous credit response to the expected declines in productivity or increases in default rates. They identify a positive productivity shock by assuming that it is associated with simultaneous increases in labor productivity and GDP and a fall in inflation. The restriction on inflation is based on the idea that inflation is driven by marginal cost, and that a positive productivity shock lowers the marginal cost. Sign restrictions are imposed on the responses of four variables over four quarters following the initial shock.

Peersman (2011) estimates the impact of three types of bank lending shocks on the euro area countries; the three shocks are lending demand shock, the lending supply shock caused by monetary policy and "lending multiplier shock". The lending supply shock caused by monetary policy corresponds to the monetary policy shock in other studies. A lending multiplier shock represents a change in loans to NFCs independent from a change in monetary policy. For instance, an innovation that makes it easier for banks to securitize their loans allows them to fund themselves by selling loans and 
enhances their ability to supply loans. Other examples are financial innovations such as credit risk transfer instruments like a credit default swap. These advances allow for the improved allocation and dispersion of risk, which would enhance the ability of banks to supply loans. Peersman (2011) uses five variables; GDP, loans, the monetary base, bank lending rate and the short-term interest rate. A loan demand shock is simply identified by a positive co-movement between loan volume and lending rate. Sign restrictions are imposed on the immediate impact and for the following four months, except for the loan volume, for which restrictions are imposed only for the third and fourth months after the shocks. These restrictions should allow for a possible short-run increase in loan volume after a rise in lending rate. For example, loans to NFCs could respond negatively with a lag, but positively at the moment of shock, because NFCs can withdraw on their credit lines at a pre-specified rate when the lending rate on new loans increases (Note 4). An expansionary monetary policy shock is assumed to reduce the lending rate and stimulate bank lending. Thus, monetary policy shock is identified only if they ultimately affect the supply of bank loans. A positive lending multiplier shock is assumed to increase the lending multiplier, defined as the difference between the (logged) loan volume and monetary base, and captures the loan volume generated by the financial sector with a specific amount of monetary base (Note 5). This restriction allows us to separate the shock from the monetary policy shock aimed at influencing the loan volume. In addition, the short-term interest rate is assumed to increase in response to a positive lending multiplier shock.

Tamási and Világi (2011) study the dynamics of the macro-economy and financial intermediary sector in Hungary. They identify four shocks: two types of loan supply shocks, monetary policy shock and the shock of the required risk premium of foreign investors. Two types of loan supply shocks are the risk assessment shock and credit spread shock. A risk assessment shock is defined as a shock that captures the changes in behavior of the management or staff of financial intermediaries. A credit spread shock is defined as a shock relating to changes in regulatory policy or environment in the financial sector, including the changes in tax levied on financial intermediaries, changes in the degree of competition, and changes in capital constraints. They use seven variables: real GDP, prices (CPI), short-term interest rate, nominal effective exchange rates, loans (composite of domestic and foreign currency bank loans), credit spread (the differences between domestic currency-denominated loans and short-term interest rate) and the default rate. In addition, they use the EURIBOR and the GDP-based indicator of foreign demand as exogenous variables. They identify a positive risk assessment shock by assuming that it simultaneously leads to an increase in default rate and loan volume. The probability of a future default rate increase makes banks reluctant to extend their loans. Therefore, the joint occurrence of a risk increasing and loan expansion must be induced by a loan supply shock. They also impose zero restrictions on the short-term interest rate at the initial date on impact, this enables us to disentangle risk assessment shock from the international risk premium shock (Note 6). A positive credit spread shock is identified by a fall in credit spread and rise in loans and real GDP (Note 7). For example, when policy makers decrease a tax on financial intermediaries, the credit spread will decrease. Furthermore, in order to distinguish a credit spread shock from a risk assessment shock, they impose zero restriction on the default rate at the initial date. An expansionary monetary policy shock is identified by depreciation of the exchange rate and increase in real GDP and prices. They do not impose any restriction on the reaction of loans to monetary policy, because it could be ambiguous. To identify the shock of the required risk premium of foreign investors, they rely on the uncovered interest rate parity with a risk premium term and assume that an unexpected decrease in risk premium leads to a decline in short-term interest rate and an appreciation of the exchange rate.

Hristov, Hülsewig and Wollmershäuser (2012) employ a panel VAR model to investigate the role of banks in 11 euro area countries after the global financial crisis in 2007. They use five variables, real GDP, prices (the GDP deflator), short-term interest rate, lending rate, and loans, and identify four shocks, the aggregate supply, monetary policy, aggregate demand, and loan supply shocks. For the aggregate supply shock, they assume that the central bank reacts to a negative aggregate supply shock by increasing the short-term interest rate, while restrictions on the lending rate and loan volume are not imposed. A contractionary monetary policy shock has a non-negative impact on the lending rate, because the lending rate is tied to the money market rate. The response of the loan volume is not restricted. For the aggregate demand shock, Hristov, et al. (2012) assume that the central bank reacts to a negative aggregate demand shock by lowering the nominal interest rate. They also assume that the lending rate would fall following a negative aggregate demand shock. This is because a negative aggregate demand shock would reduce the loan demand, which leads to a fall in the lending rate on the one hand, while a reduction in money market rate is passed-through to the lending rate on the other hand. For a negative loan supply shock, the real GDP declines after the shock. However, these restrictions are not sufficient to disentangle the loan supply shock from contractionary aggregate supply and monetary policy shocks, which simultaneous induce a decline in loan volume and an increase in lending rate. Thus, the central bank is assumed to react to a negative loan supply shock by lowering the short-term nominal interest rate. This assumption enables us to identify the loan supply shock, because both contractionary aggregate supply and monetary policy shocks increase the short-term interest rate.

Gambetti and Musso (2012) investigate the role of loan supply shock in the business cycle in the euro area, the United 
Kingdom and the United States by employing a time-varying VAR model. They use five variables, real GDP, inflation, loan volume, lending rate and short-term interest rate, and identify three shocks, the loan supply, aggregate supply, and aggregate demand shocks. For a positive loan supply shock, they restrict the positive response of real GDP, but do not restrict the responses of inflation and short-term interest rate because they are ambiguous. As regards the aggregate supply and aggregate demand shocks, expansionary shocks are assumed to induce an increase in the loan demand and lead to an increase in the loan volume as well as lending rate (Note 8). Restrictions are imposed on the lending rate but not on the spread between the lending rate and short-term interest rate, because short-term interest rate could be influenced by other shocks.

Kabashi and Suleva (2012) analyze loan supply shock effects of Macedonia. They use five variables, GDP growth, inflation, the short term interest rate, the lending rate, and the change in loan volume, and, following Hristov et al. (2012), identify four shocks, the aggregate supply, monetary policy, aggregate demand and loan supply shocks. They assume that the central bank reacts to a negative aggregate supply shock with a contractionary monetary policy and to negative aggregate demand shock with an expansionary monetary policy. In addition, a negative aggregate demand shock is accompanied by a contemporaneous fall in lending rate for two reasons. First, a lower aggregate demand results in a lower loan demand, which is accompanied by lower lending rate. Second, the lower policy rate in response to a negative demand shock also leads to a lower lending rate. As for loan supply shock, they assume that the GDP growth falls following negative loan supply shock. While there is little agreement with regard to the reaction of monetary policy, Kabashi and Suleva (2012) assume that the central bank lowers the policy rate. This restriction enables us to distinguish the loan supply shock from the aggregate supply and monetary policy shocks, which come with rising policy rates. No restrictions are imposed on prices.

Table 2. Literature review

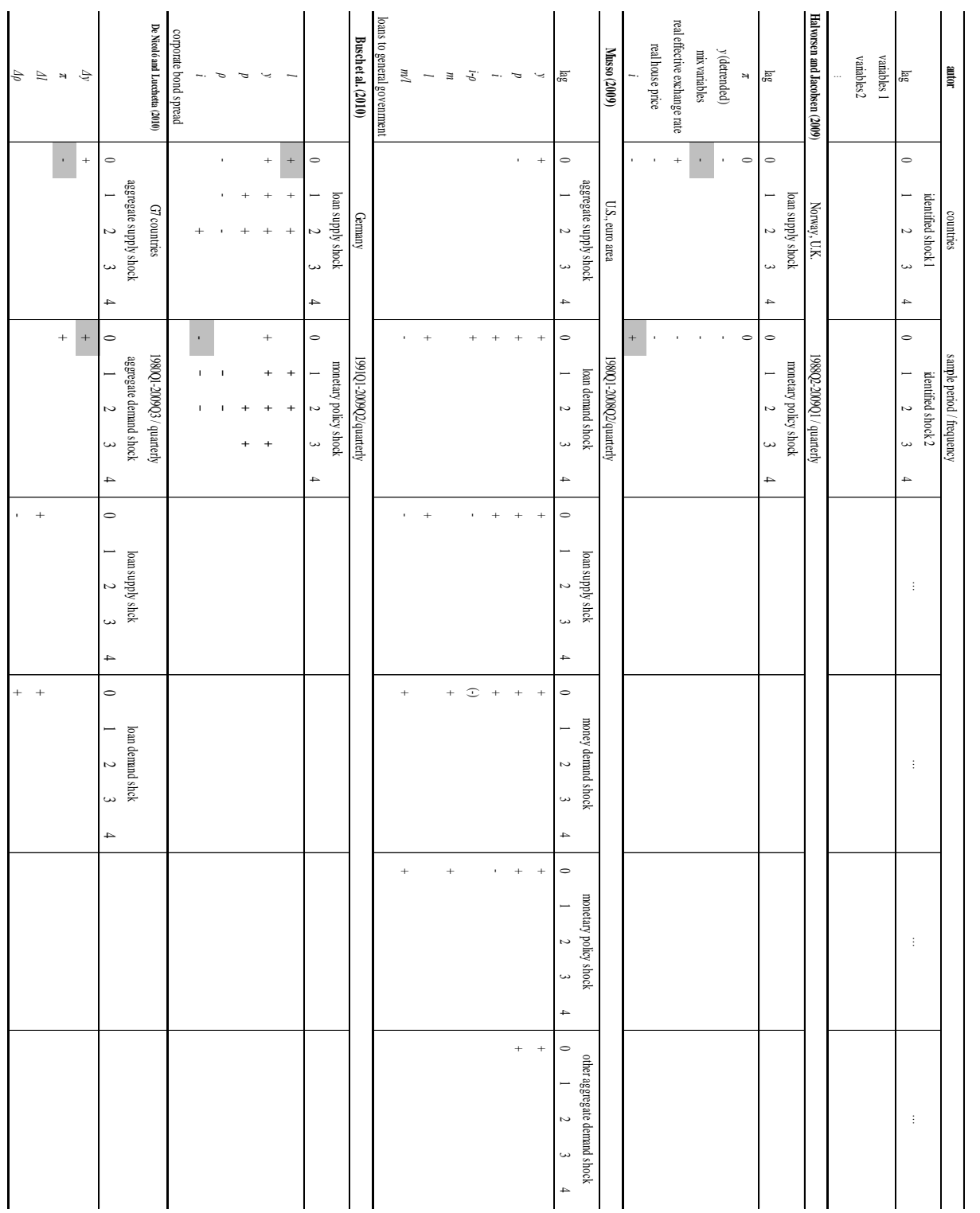




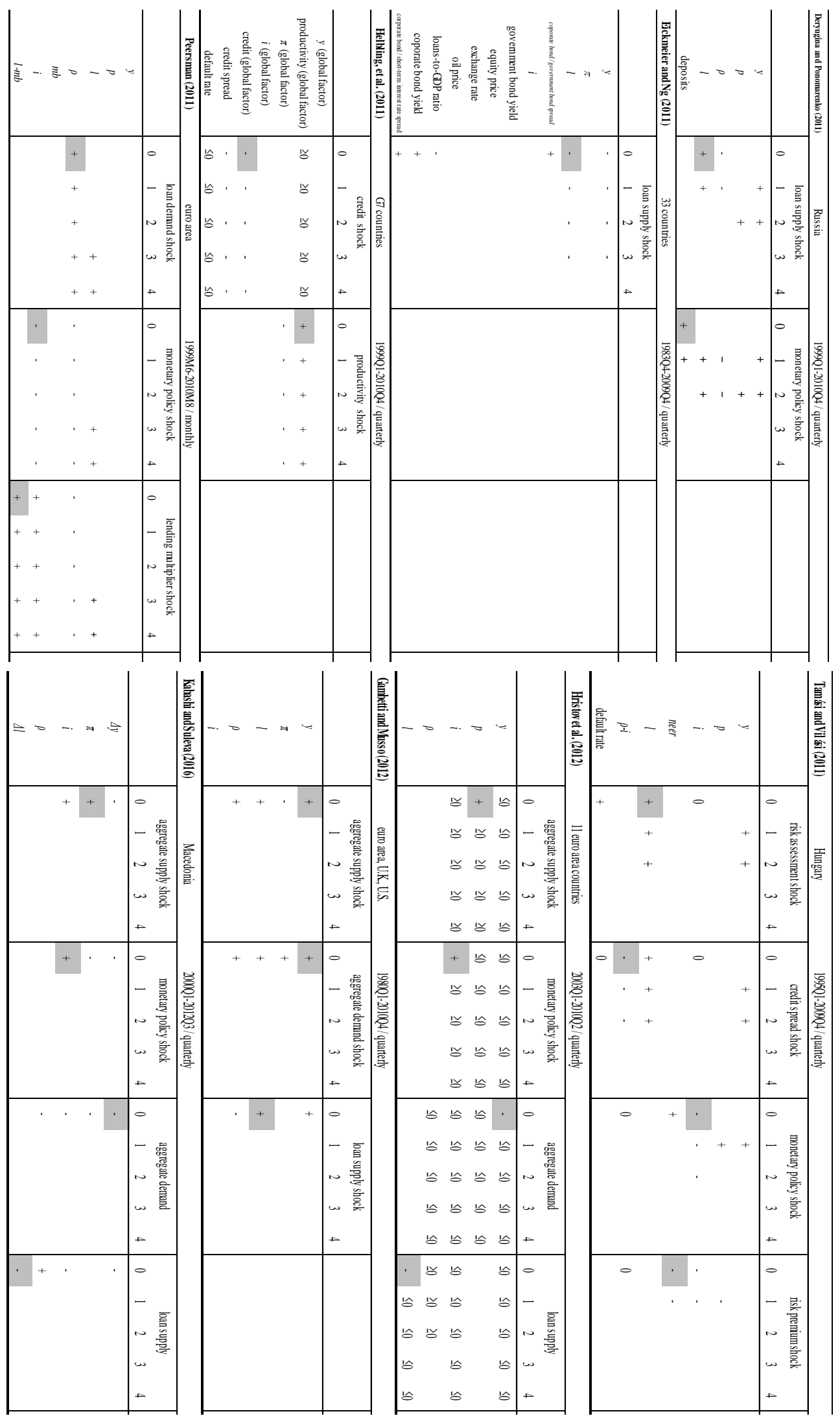

Notes: $y$ : output; $p$ : prices; $\pi$ : inflation rates; $i$ : short-term nominal interest rate; $\rho$ : bank lending rate; $m b$ : monetary base; $m$ : money supply; $l$ : bank loans. 


\section{Estimation}

\subsection{Methodology}

\subsubsection{Sign Restrictions VAR}

We assume that the structural-form VAR model can be represented as

$$
A X_{t}=A_{1} X_{t-1}+A_{2} X_{t-2}+\cdots+A_{p} X_{t-p}+\varepsilon_{t}, \quad \varepsilon_{t} \sim i . i . d .\left(0, I_{k}\right)
$$

where $X_{t}$ is a $k \times 1$ vector of data, $p$ is a lag order, $A$ is a $k \times k$ contemporaneous coefficient matrix, $A_{i}$ $(i=0,1,2, \cdots, p)$ are $k \times k$ coefficient matrices, and $\varepsilon_{t}$ is a $k \times 1$ unobservable structural shock vector; these are mutually independent and can be normalized to have a variance 1 .

To estimate the model, we need to derive a reduced-form VAR model, which corresponds to the structural-form VAR model in equation (1).

$$
\begin{aligned}
X_{t} & =B_{1} X_{t-1}+B_{2} X_{t-2}+\cdots+B_{p} X_{t-p}+u_{t} \\
& =B(L) L^{-1} X_{t-1}+u_{t} \quad, \quad u_{t} \sim i . i . d .\left(0, \Sigma_{u}\right) \\
& \equiv C(L) X_{t-1}+u_{t}
\end{aligned}
$$

where $B_{i}=A^{-1} A_{i}, \quad B_{i} \quad(i=1,2, \cdots, p)$ are $k \times k$ coefficient matrices, $u_{t}$ is a reduced-form shock, and $B(L) \equiv B_{1} L+B_{2} L^{2}+\cdots+B_{p} L^{p} \quad$ is a matrix polynomial in the lag operator $L$.

By comparing equations (1) and (2), we obtain

$$
\begin{gathered}
B_{i}=A^{-1} A_{i}(i=1,2, \cdots, p) \\
u_{t}=A^{-1} \varepsilon_{t} \\
\Sigma_{u}=A^{-1}\left(A^{-1}\right)^{\prime} .
\end{gathered}
$$

Thus, we can identify structural shock $\varepsilon_{t}$ as $\varepsilon_{t}=A u_{t}$. While matrix $A$ contains $k^{2}$ parameters, the estimated symmetric variance-covariance matrix $\Sigma_{u}$ contains $k(k+1) / 2$ elements. Consequently, we need to impose $k^{2}-k(k+1) / 2=k(k-1) / 2$ additional restrictions on matrix $A$. We therefore restrict matrix $A$ to a lower triangular as implied by the Cholesky decomposition. The important point to note is that the Cholesky decomposition here is just a way to orthogonalize shocks rather than an identification strategy. Let us denote the Cholesky factor of $\Sigma_{u}$ as $P$. Then, in this special case, $A^{-1}=P$, since $\Sigma_{u}=A^{-1}\left(A^{-1}\right)^{\prime}=P P^{\prime}$. However, this is just one possible solution. We can decompose $\Sigma_{u}=A^{-1}\left(A^{-1}\right)^{\prime}=\tilde{P} \tilde{P}^{\prime}$, where $\tilde{P}=P Q^{\prime}$ and $Q$ is an orthogonal matrix with $Q^{\prime} Q=Q Q^{\prime}=I_{k}$, because $\tilde{P} \tilde{P}^{\prime}=\left(P Q^{\prime}\right)\left(P Q^{\prime}\right)^{\prime}=P Q^{\prime} Q P^{\prime}=P P^{\prime}=\Sigma_{u}$. Thus, for any decomposition $\Sigma_{u}=\left(A^{-1}\right)\left(A^{-1}\right)^{\prime}$, there exist infinitely many identification strategies. Matrix $Q$ is called a rotation matrix, because it rotates the initial Cholesky matrix $P$ while maintaining the orthogonality that shocks are mutually independent.

The sign restrictions VAR methodology, which identifies the structural shocks subject to a set of sign restrictions, consists of six steps (Note 9).

The first step estimates reduced-form VAR model in equation (2) to obtain $\hat{C}$ and $\hat{\Sigma}_{u}$, where $C=\left[C_{1}{ }^{\prime} \cdots C_{p}{ }^{\prime}\right]$ and the "hat ( ")" represents the ordinary least squares (OLS) estimates of coefficients and variance-covariance matrix. Then, take a draw $\left(C, \Sigma_{u}\right)$ from the posterior of the reduced form parameters. Most of the studies use a Normal-Wishart distribution for $\left(C, \Sigma_{u}\right)$ (e.g., Uhlig, 2005).

The second step computes the Cholesky decomposition of $\Sigma_{u}=P P^{\prime}$. As mentioned above, the Cholesky decomposition here is just a way to orthogonalise shocks rather than an identification strategy.

The third step draws an orthogonal matrix $Q$ randomly. Drawing matrix $Q$ is based on a Givens rotation in Uhlig (2005) and on a QR decomposition in Rubio-Ramirez, Waggoner, and Zha (2010). As regards the Givens rotation, rotation angles $\theta$ are drawn from a uniform distribution $U(0, \pi)$. For the case of QR decomposition, the $k \times k$ matrix $K$ is drawn from $N(0,1)$ density and then takes the $\mathrm{QR}$ decomposition of $K$ such that $K=Q R$, $Q Q^{\prime}=I_{k}$, and $R$ is a triangle matrix. Fry and Pagan (2011) show that both algorithms are equivalent.

The fourth step computes impulse responses using $A^{-1}=P Q^{\prime}$. Equation (2) can be rewritten as 


$$
\begin{gathered}
{\left[I_{k}-B(L)\right] X_{t}=u_{t}} \\
X_{t}=\left[I_{k}-B(L)\right]^{-1} u_{t}
\end{gathered}
$$

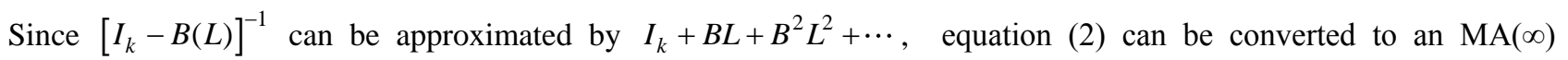
model as

$$
X_{t}=\left[I_{k}-B(L)\right]^{-1} u_{t}=I u_{t}+B u_{t-1}+B^{2} u_{t-2}+\cdots .
$$

Note that because $u_{t}=A^{-1} \varepsilon_{t}$, the structural impulse response functions can be computed as

$$
\frac{\partial X_{t+h}}{\partial \varepsilon_{t}}=\frac{\partial X_{t+h}}{\partial u_{t}} \frac{\partial u_{t}}{\partial \varepsilon_{t}} X_{t}=\left(I+B+B^{2}+\cdots\right) A^{-1}=\left(I+B+B^{2}+\cdots\right) P Q^{\prime}
$$

The fifth step checks whether the impulse response functions satisfy the imposed sign restrictions. If the answer is yes, keep the responses, otherwise, discard it.

Finally, repeat steps 3 to 5, until a large number of models are accepted.

\subsubsection{Variables, Identified Shocks and Sign Restrictions}

We choose the variables included in our VAR model from a version of the Bernanke-Blinder model, where six endogenous variables, output $(y)$, prices $(p)$, bank reserves $(r s)$, bond rate $(i)$, bank lending rate $(\rho)$ and loans $(l)$, are determined from six equations, the aggregate demand curve, aggregate supply curve, monetary policy rule, money demand curve, loan demand curve and loan supply curve. We assume that the monetary policy operating instrument is the reserve supply (the outstanding current account balance at the BOJ), consistent with the fact that the BOJ has adopted reserve supply as the main operating instrument since March 2001.

Since we have six endogenous variables, we could identify at most six structural shocks. However, we identify four shocks, the aggregate demand, monetary policy, loan demand and loan supply shocks. As mentioned in the Introduction, three conditions must be satisfied for a bank lending channel to exist. Condition (i) implies that the loan supply must depend on the bank reserves and bank lending rate (or spread between bank lending rate and bond rate) positively, while condition (ii) implies that the loan demand must depend on the bank lending rate (or spread) negatively. Condition (iii) is that the aggregate demand must depend on the bank lending rate negatively. Therefore, for a bank lending channel to exist, there must be a long-run stable aggregate demand curve, monetary policy rule, loan demand curve, and loan supply curve, corresponding to the aggregate demand, monetary policy, loan demand and loan supply shocks, respectively.

Our sign restrictions are summarized in Table 3. A positive aggregate demand shock is defined as a shock whose initial impact increases $y$ at date 0 . We assume that $p$ increases with a lag of four months owing to short-term price stickiness. $l$ also increases with a lag of four months, because an increase in $y$ stimulates firms' investment and thus the firms' loan demand, which would have a positive pressure on $\rho$. A quantitative easing monetary policy shock is defined as a shock which increases $r s$ at date 0 . We assume that it increases both $y$ and $p$ with a lag of four months. We also assume that $l$ increases for two reasons. First, as in the Bernanke-Blinder model, when the required reserves and the fraction of banks' net of required reserves assets held in loans depend positively on the volume of deposits, the increase in bank reserves directly increases the loan supply. Second, as mentioned above, the increase in $y$ stimulates firms' investment and thus the firms' loan demand. The impact on $\rho$ is ambiguous depending on the magnitudes of shifts in the loan supply and loan demand curves. We do not impose restrictions on $i$, because the short-term interest rates are close to the zero lower bound in Japan during our sample periods. Following the previous studies, we assume that loan supply shock moves the loan volume and lending rate in opposite directions, whereas a loan demand shock moves them in the same direction. Thus, we define a positive loan demand shock as a shock that increases both $l$ and $\rho$ at time 0 , whereas a positive loan supply shock as a shock that increases $l$ but decreases $\rho$ at time 0 . We also assume that both positive loan demand and supply shocks increase $y$ after four months. 
Table 3. Sign restrictions

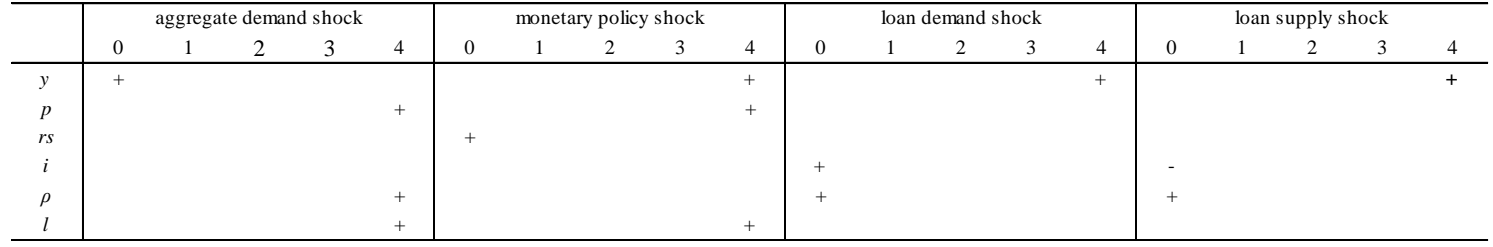

\subsection{Data}

Our data set is similar to that used in Kumamoto and Zhuo (2015).

In response to the failure of large financial institutions in autumn 1997, the Bank of Japan (BOJ) lowered the overnight call rate to $0.02 \%$ in February 1999, and it faced zero lower bound on the nominal interest rate. Thus, in March 2001, the BOJ decided to adopt "Quantitative Monetary Easing (QE)" policy, under which it controls its outstanding current account balances as the main operating instrument, and it raised the target level of the current account balance. In April 2013 the BOJ introduced "Quantitative and Qualitative Monetary Easing (QQE)" policy, under which it aims to achieve the inflation target of 2 percent with a time horizon about two years, and double the monetary base and the amounts outstanding of Japanese government bonds (JGB) as well as exchange-traded funds (ETFs), and more than double the average remaining maturity of JGB purchases. It means that there will be possible structural breaks in the transmission mechanism of monetary policy since 2013. From above considerations, we set the sample period from January 2000 to December 2012.

We calculate the data on $y$ by interpolating the quarterly data on real GDP to monthly data using the Chow and Lin (1971) method (Note 10). As mentioned above, we focus on the differential effects of quantitative easing monetary policy regardless of bank and enterprise size. Thus, we consider three categories of Japanese banks based on their size on the lending side: all banks, City banks, and Regional I and II banks (hereafter, Regional banks) (Note 11). We also consider two categories of enterprises based on their borrowing side: all enterprises (corporations), and small and medium-sized enterprises (hereafter SMEs). Thus, the data on bank lending are classified into six categories-(i) $l_{a a}$ : all banks' loans to all firms (hereafter $a a$ ); (ii) $l_{a s}$ : all banks' loans to SMEs ( $a s$ ); (iii) $l_{c a}$ : City banks' loans to all enterprises ( $c a$ ); (iv) $l_{c s}$ : City banks' loans to SMEs ( cs ); (v) $l_{r a}$ : Regional banks' loans to all firms ( $r a$ ); and (vi) $l_{r s}$ : Regional banks' loans to SMEs ( $\left.r s\right)$, where we calculate $l_{a a}=l_{c a}+l_{r a}$ and $l_{a s}=l_{c s}+l_{r s}$. The data on bond rate $i$ are the 10-year government bond yield. As for the data on bank lending rate, we categorize three types of data based on the average contract interest rate on loans according to the three categories of banks: the average contract interest rate on loans of all banks $\rho_{a}$ for $a a$ and as; that on loans of City banks $\rho_{c}$ for ca and $c s$; and that on loans of Regional banks $\rho_{r}$ for $r a$ and $r s$, where we calculate $\rho_{a}$ as a weighted average of $\rho_{c}$ and $\rho_{r}$ with weights calculated from $l_{c}=l_{c a}+l_{c s}$ and $l_{r}=l_{r a}+l_{r s}$. As for data on the outstanding balance of the BOJ's current accounts $r s$, we proxy it as the deposit paid data on the assets side of the banks' balance sheet, owing to limited data availability. We use three types of deposits paid data in accordance with the three categories of banks: the deposit paid data of all banks $r s_{a}$ for $a a$ and $a s$; those of City banks $r s_{c}$ for $c a$ and $c s$; and those of Regional banks $r s_{r}$ for $r a$ and $r s$, where we calculate $r s_{a}=r s_{c}+r s_{r}$. The above data can be obtained from the BOJ.

\subsection{Results and Discussions}

Figure 1 displays the impulse response functions of $y, p, i, \rho$ and $l$ with respect to the quantitative easing monetary policy shock on $r s$ for 36 periods (3 years). From the figures, the responses of $l_{r a}$ and $l_{r s}$ on impact are slightly larger than those of others. An important point to note is that while $\rho_{r}$ declines in larger magnitude following a quantitative easing monetary policy shock, $\rho_{a}$ declines in smaller magnitude and $\rho_{c}$ increases. The co-existence of the decline in $\rho_{r}$ and increases in $l_{r a}$ and $l_{r s}$ means that the loan supply of Regional bank increases more than the loan demand, which is evidence of the bank lending channel. Moreover, the responses of $y$ to $r s$ are the largest (although slightly) in the case of $r s_{r}$. These results together mean that a quantitative easing policy has a greater impact of on the real economy through bank lending by Regional banks.

Table 4 summarizes the variance decomposition results, that is, the proportion of forecast error variance explained by each shock. Here, we show the averaged short-term (1-12 months), middle-term (13-24 months), long-term (25-36 months) and the full-term (1-36 months) variance decomposition for selected series: the proportion of the forecast error variance of $l$ explained by monetary policy shock (we note this as "monetary policy $\rightarrow l$ " in the table), that of $\rho$ explained by loan supply shock ("loan supply $\rightarrow \rho$ "), that of $y$ explained by loan supply shock ("loan supply $\rightarrow$ $y$ ") and that of $y$ explained by monetary policy shock ("monetary policy $\rightarrow y$ "). As for "monetary policy $\rightarrow l$," a comparison of the results of $c a$ and $c s$ with $r a$ and $r s$ shows that a larger proportion of the forecast error variance of loans of Regional banks can be explained by monetary policy shock than that of City banks. Moreover, by 
comparing $a a$ with as, $c a$ with $c s$, and $r a$ with $r s$, we find that the loans to SMEs are more influenced by monetary policy shock than those to all firms. As for "loan supply $\rightarrow \rho$," the bank lending rate of Regional banks is more affected by a loan supply shock than is that of City banks in the short term, meaning that the loan supply curve of Regional banks shifts to the right in a larger magnitude in the short term and is consistent with the impulse response function results. On the other hand, in the middle and long-terms, the bank lending rate of City banks is more affected by a loan supply shock. As for "loan supply $\rightarrow y$," we see that the loans of Regional banks have a larger impacts on output than the loans of City banks, and we also see that loans to SMEs have a larger impact on output than the loans to all firms. As for "monetary policy $\rightarrow y$," output is more affected by the reserve supply to Regional banks than that to City banks. These results together indicate that quantitative easing policy can have a greater impact on the real economy through bank lending by Regional banks. They are consistent with Kashyap and Stein (1994) and Gertler and Gilchrist (1993, 1994), who find the loans of smaller banks as well as the loans to bank-dependent smaller firms more sensitive to monetary policy.
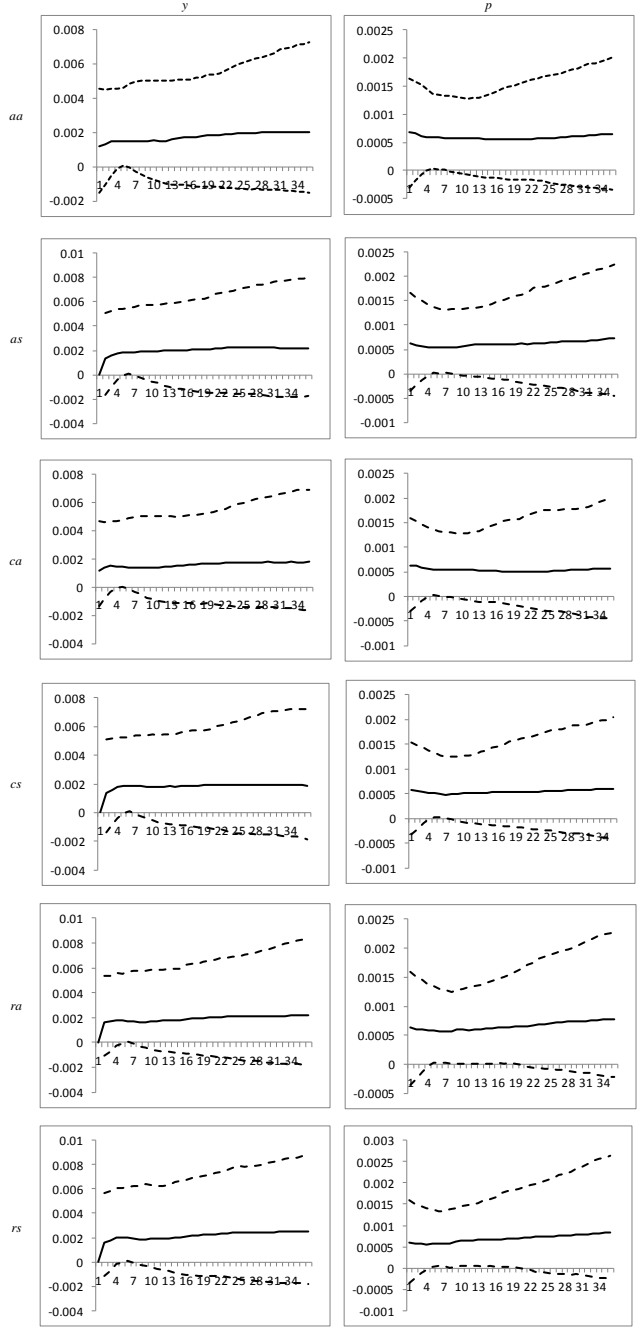
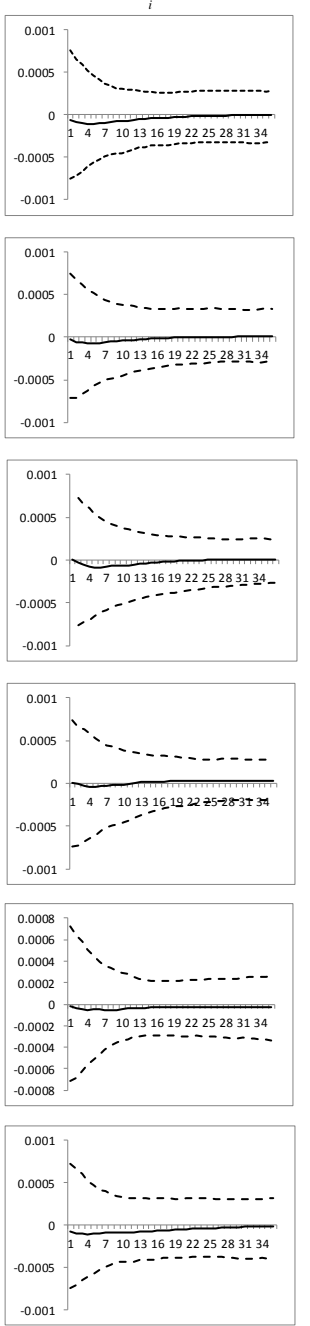
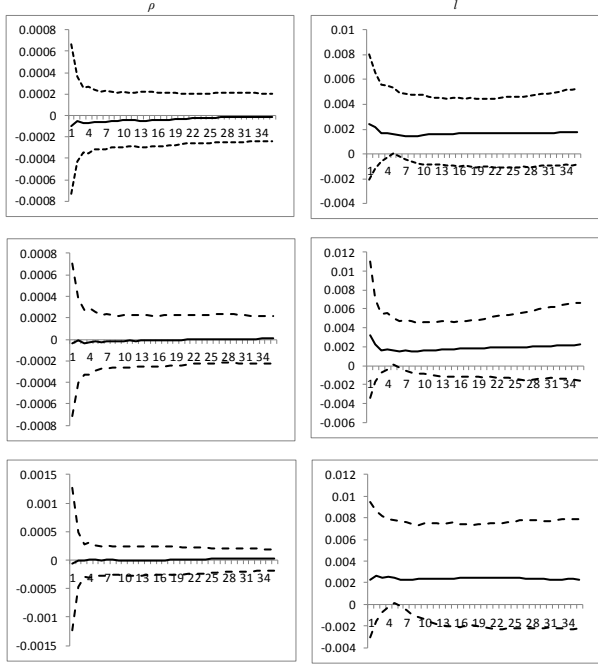

$-0.002]$

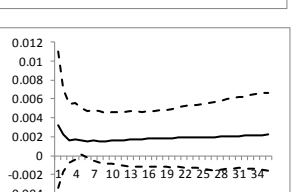
-0.002
-0.004
-0.006

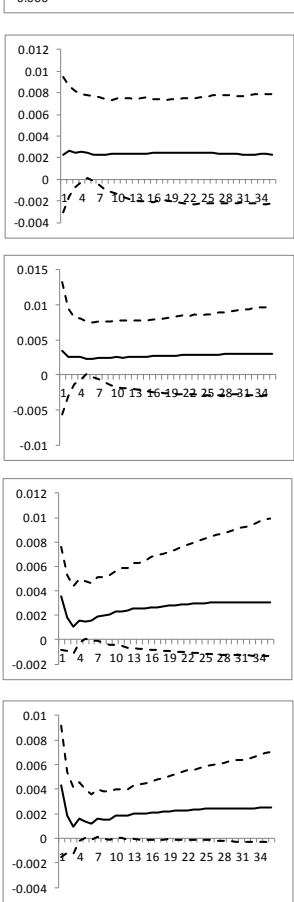

Figure 1. Impulse response functions to quantitative easing monetary policy shock 
Table 4. Variance decompositions (in percent)

\begin{tabular}{ccccccc}
\hline monetary policy $\rightarrow l$ & $a a$ & $a s$ & $c a$ & $c s$ & $r a$ & $r s$ \\
\hline $1-12$ periods & 6.5 & 7.8 & 5.2 & 6.5 & 11.0 & 14.2 \\
13-24 periods & 8.9 & 10.1 & 7.3 & 8.5 & 12.9 & 18.7 \\
25-36 periods & 11.6 & 12.1 & 9.0 & 9.4 & 15.5 & 22.6 \\
1-36 periods & 9.0 & 10.0 & 7.2 & 8.2 & 13.1 & 18.5 \\
\hline \hline loan supply $\rightarrow \rho$ & $a a$ & $a s$ & $c a$ & $c s$ & $r a$ & $r s$ \\
\hline 1-12 periods & 14.8 & 13.9 & 13.8 & 11.9 & 16.3 & 14.4 \\
13-24 periods & 14.4 & 14.8 & 15.7 & 14.9 & 14.2 & 12.3 \\
25-36 periods & 14.7 & 15.0 & 16.4 & 15.9 & 12.6 & 12.7 \\
1-36 periods & 14.7 & 14.6 & 15.3 & 14.2 & 14.3 & 13.1 \\
\hline \hline loan supply $\rightarrow y$ & $a a$ & $a s$ & $c a$ & $c s$ & $r a$ & $r s$ \\
\hline $1-12$ periods & 5.9 & 7.2 & 5.8 & 6.9 & 6.7 & 7.3 \\
13-24 periods & 9.2 & 10.6 & 8.0 & 8.5 & 9.2 & 11.0 \\
25-36 periods & 11.3 & 12.5 & 9.7 & 9.1 & 10.7 & 12.5 \\
1-36 periods & 8.8 & 10.1 & 7.8 & 8.2 & 8.9 & 10.3 \\
\hline \hline monetary policy $\rightarrow y$ & $a a$ & $a s$ & $c a$ & $c s$ & $r a$ & $r s$ \\
\hline 1-12 periods & 5.2 & 7.2 & 4.8 & 7.0 & 6.8 & 7.7 \\
$13-24$ periods & 7.2 & 9.7 & 6.3 & 8.7 & 7.3 & 8.8 \\
25-36 periods & 9.4 & 11.6 & 7.9 & 9.3 & 8.5 & 10.8 \\
1-36 periods & 7.3 & 9.5 & 6.4 & 8.3 & 7.5 & 9.1 \\
\hline
\end{tabular}

\section{Conclusions}

This paper investigates the existence of a bank lending channel in Japan since the beginning of the quantitative easing monetary policy in the early 2000s. We employ the sign restrictions VAR approach to overcome the identification problem, assuming that the monetary policy operating instrument is the reserve supply, which is consistent with the fact that the BOJ has adopted the reserve supply as the main operating instrument since March 2001. We choose six endogenous variables, output, prices, bank reserves, bond rate, bank lending rate and loans, and identify four structural shocks, the aggregate demand, monetary policy, loan demand, and loan supply shocks. In particular, we focus on the differential effects of the quantitative easing monetary policy regardless of bank and enterprise size.

Our impulse response function analyses show that following a quantitative easing monetary policy shock, the loans of Regional banks increases more than those of City banks, and the bank lending rate of Regional banks declines in a larger magnitude. Moreover, the responses of output to reserve supply in Regional bank are larger than that in City banks.

Our variance decomposition analyses show that a larger proportion of the forecast error variance in the bank lending of Regional banks relative to City banks and a larger proportion of the forecast error variance in the bank loans to SMEs relative to all firms can be explained by monetary policy shock. Similarly, the loans of Regional banks have a larger impact on output than those of City banks and the loans to SMEs have a larger impact on output than those to all firms. Moreover, output is affected more by the reserve supply to Regional banks than that to City banks. These results together indicate that a quantitative easing policy has a greater impact on the real economy through the bank lending of Regional banks. These results are consistent with Kashyap and Stein (1994) and Gertler and Gilchrist (1993, 1994), who find that the loans of smaller banks as well as the loans to bank-dependent smaller firms are more sensitive to monetary policy.

\section{References}

Baumeister, C. (2014). Identification of VAR models with sign restrictions: Traditional approach. Advanced Bayesian Econometrics: Structural and Time-varying VAR Models, CIDE Summer School.

Bernanke, B. S., \& Blinder, A. S. (1988). Credit, money, and aggregate demand. American Economic Review Papers and Proceedings, 78(2), 435-439. https://doi.org/10.3386/w2534

Busch, U., Scharnagl, M., \& Scheithauer, J. (2010). Loan supply in Germany during the financial crisis. Deutsche Bundesbank Economic Studies Discussion Paper, No. 05/2010.

Chow, G. C., \& Lin A. (1971). Best linear unbiased interpolation, distribution and extrapolation of time series by related series. Review of Economics and Statistics, 53(4), 372-375. https://doi.org/10.2307/1928739

De Nicolò, G., \& Lucchetta, M. (2010). Systemic risks and the macroeconomy. IMF Working Papers 10/29. https://doi.org/10.5089/9781451962567.001

Deryugina, E. B., \& Ponomarenko, A. A. (2011). Identifying structural shocks behind loan supply fluctuations in Russia. BOFIT Discussion Paper, No. 20/2011. https://doi.org/10.2139/ssrn.1914297 
Eickmeier, S., \& Ng, T. (2011). How do credit supply shocks propagate internationally? A GVAR approach. Deutsche Bundesbank Economic Studies Discussion Paper, No. 27/2011.

Fry, R., \& Pagan, A. (2011). Sigh restrictions in structural vector autoregressions: A critical review. Journal of Economic Literature, 49(4), 938-960. https://doi.org/10.1257/jel.49.4.938

Gambetti, L., \& Musso, A. (2012). Loan supply and the business cycle. ECB Working Paper Series, No.1469. https://doi.org/10.1002/jae.2537

Gertler, M., \& Gilchrist, S. (1993). The role of credit market imperfections in the monetary transmission mechanism: Arguments and evidence. The Scandinavian Journal of Economics, 95(1), 43-64. https://doi.org/10.2307/3440134

Gertler, M., \& Gilchrist, S. (1994). Monetary policy, business cycles, and the behavior of small manufacturing firms. The Quarterly Journal of Economics, 109(2), 309-340. https://doi.org/10.2307/2118465

Halvorsen, J. I., \& Jacobsen, D. H. (2009). Are bank lending shocks important for economic fluctuations. Norges Bank Working Paper, No. 2009/27.

Helbling, T., Huidrom, R., Kose, M. A., \& Otrok, C. (2011). Do credit shocks matter? A global perspective. European Economic Review, 55, 340-353. https://doi.org/10.1016/j.euroecorev.2010.12.009

Hristov, N., Hülsewig, O., \& Wollmershäuser, T. (2012). Loan supply shocks during the financial crisis: Evidence for the Euro Area. Journal of International Money and Finance, 31(3), 569-592. https://doi.org/10.1016/j.jimonfin.2011.10.007

Kabashi, R., \& Suleva, K. (2012) Loan supply shocks in Macedonia: A Bayesian SVAR approach with sign restrictions. mimeo.

Kashyap, A. K., \& Stein, J. C. (1994). Monetary policy and bank lending. In N. G. Mankiw (Ed.), Monetary policy, (pp. 221-261). Chicago.IL: University of Chicago Press.

Kashyap, A. K., \& Stein, J. C. (2000). What do a million observations on banks say about the transmission of monetary policy? American Economic Review, 90, 407-428. https://doi.org/10.1257/aer.90.3.407

Kashyap, A. K., Stein, J. C., \& Wilcox, D. W. (1993). Monetary policy and credit conditions: Evidence from the composition of external finance. American Economic Review, 83, 78-98.

Kimura, T., Kobayashi, H., Muranaga, J., \& Ugai, H. (2003). The effects of the increase in the monetary base on Japan's economy at zero interest rates: An empirical analysis. BIS papers 19, 276-312.

Krugman, P. R. (1998a) Japan's trap. mimeo. Retrieved from http://web.mit.edu/Krugman/www/japtrap.html.

Krugman, P. R. (1998b). Further notes on Japan's liquidity trap, mimeo. Retrieved from http://web.mit.edu/Krugman/www/liquid.html.

Kumamoto, M., \& Zhuo. J. (2015) Bank lending channel in transmission of monetary policy in Japan, 2000-2012: Bayesian estimation analysis. Applied Economics and Finance, 3(1), 23-37. https://doi.org/10.11114/aef.v3i1.1198

Musso, A. (2009). Money and credit over the business cycle. mimeo. Retrieved from http://www.faculty.ucr.edu/ chauvet/ucrconference_files/musso.pdf

Peersman, G. (2011). Bank lending shocks and the euro area business cycle. Universiteit Gent Working Paper 2011/766. Retrieved form http://wps-feb.ugent.be/Papers/wp_11_766.pdf

Rubio-Ramirez, J. F., Waggoner, D. F., \& Zha, T. (2010). Structural vector autoregressions: Theory of identification and algorithms for inference. Review of Economic Studies, 77(2), 665-696. https://doi.org/10.1111/j.1467-937X.2009.00578.x

Tamási, B., \& Világi, B. (2011). Identification of credit supply shocks in a Bayesian SVAR model of the Hungarian economy. Magyar Nemzeti Bank Working Paper, No. 7/2011.

Uhlig, H. (2005). What are the effects of monetary policy on output? Results from an agnostic identification procedure. Journal of Monetary Economics, 52(2), 381-419. https://doi.org/10.1016/j.jmoneco.2004.05.007 


\section{Notes}

Note 1. See Kimura, Kobayashi, Muranaga, and Ugai (2003) for the recent developments in monetary policy in Japan.

Note 2. See Kumamoto and Zhuo (2015) for a survey of these previous studies.

Note 3. Musso (2009) calls it the "other aggregate demand" shock.

Note 4. Peersman (2011) points out that this identification does not take into account the possibility of banks increasing the supply of loans to riskier firms at a higher interest rate.

Note 5. Thus, lending multiplier shocks could include the depositors' substitution from their deposits to currency, which could limit the capacity of banks to offer loans. If banks cannot perfectly substitute their sources of funding, the loan supply and the multiplier effect decline.

Note 6. They do not impose any restrictions on credit spread so as to consider an environment with credit rationing, when it is possible to expand credit without reducing the credit rates.

Note 7. In contrast, no restrictions on the spread are placed in the case of risk assessment shock.

Note 8. In this identification, the aggregate demand shock includes the loan demand shock.

Note 9. See Uhlig (2005), Busch, et al. (2010), and Baumeister (2014) for details

\section{Copyrights}

Copyright for this article is retained by the author(s), with first publication rights granted to the journal.

This is an open-access article distributed under the terms and conditions of the Creative Commons Attribution license which permits unrestricted use, distribution, and reproduction in any medium, provided the original work is properly cited. 